Research Article

\title{
Synthesis of High-Quality Carboxyl End-Functionalized Poly(3-hexylthiophene)/CdSe Nanocomposites
}

\author{
He-Ping Shi, ${ }^{1}$ Da-Wei Lin $\mathbb{D}^{2},{ }^{2}$ and Rui-feng $W u\left(\mathbb{D}{ }^{2}\right.$ \\ ${ }^{1}$ College of Science, Inner Mongolia Agricultural University, Hohhot, Inner Mongolia 010018, China \\ ${ }^{2}$ College of Chemical Engineering, Inner Mongolia University of Technology, Hohhot 010051, China \\ Correspondence should be addressed to Rui-feng Wu; rfwu02@163.com
}

Received 26 September 2018; Accepted 18 August 2019; Published 15 September 2019

Guest Editor: Kakarla R. Reddy

Copyright (C) 2019 He-Ping Shi et al. This is an open access article distributed under the Creative Commons Attribution License, which permits unrestricted use, distribution, and reproduction in any medium, provided the original work is properly cited.

Carboxyl end-functionalized poly(3-hexylthiophene) (P3HT-COOH) was grafted chemically with CdSe nanocrystals (NCs) by a phosphine-free method. The particle quality of $\mathrm{P} 3 \mathrm{HT}-\mathrm{COOH} / \mathrm{CdSe}$ nanocomposites was better than that of $\mathrm{P} 3 \mathrm{HT} / \mathrm{CdSe}$ nanocomposites, which were synthesized using the same method. Nanocrystals with controllable particle size exhibited a wurtzite crystalline structure and showed excellent nanocrystal dispersion in the P3HT-COOH matrix. Photoluminescence (PL) characterization performed on nanocomposites suggested the efficient charge transfer at the P3HT-COOH/CdSe interface. This approach based on the phosphine-free method is not only environmentally friendly but also highly efficient.

\section{Introduction}

P3HT has been extensively utilized as conjugated polymers (CPs) for CP/CdSe nanocomposites due to its well-matched energy level with CdSe [1-5]. However, P3HT/CdSe was widely prepared by physically mixing $\mathrm{P} 3 \mathrm{HT}$ and CdSe. Phase separation of $\mathrm{P} 3 \mathrm{HT}$ and CdSe is inevitable, thereby limiting the direct electronic interaction between them [6-8]. Grafting P3HT with CdSe by a chemical method is an effect strategy to eliminate phase separation and to promote the electronic interaction between P3HT and CdSe $[6,8]$. Previously, the ligand exchange process was used to graft CPs to NCs because the derivatization of the composite has a broad range of functional groups $[9,10]$. In spite of the fact that the original ligands can be replaced by the desired ligands, NCs still tend to aggregate when mixed with CPs, which leads to phase separation [11-14].

A strategy to decrease or eliminate macrophase separation is to use end-functionalized P3HT as ligands [2, 8, 15-17]. End-functionalized P3HT equipped with alcohol, ethynyl, carboxylic acid, pyridines, thiols, amine, and phosphate groups has been developed [14, 17-19]. The research shows that it also generates chemically defined interfaces that improve elec- tronic communication between the CPs and NCs. Polythiophene with carboxylic acid functional groups has been used to prepare many nanocomposites because it increases the interactions at the interface with the NCs [20-22]. Photoinduced electron transfer from CPs to NCs was also improved by replacing the P3HT with P3HT-COOH [23].

Many works on the synthesis of $\mathrm{CP} / \mathrm{NC}$ nanocomposites have been reported $[9,19,24-31]$. But some key chemicals, such as tri-n-octylphosphine oxide (TOPO) and trioctylphosphine (TOP), used in traditional routes are extremely toxic, expensive, explosive, and pyrophoric $[7,11,12,28,31]$. So phosphine-free synthesis schemes have extended to green and low-cost cadmium carboxylate precursors, fatty acid ligands, and noncoordination solvents (ODE, heat transfer fluids, and paraffin liquid) [32-34]. P3HT/CdSe has been successfully synthesized in ODE without using TOP and TOPO [4]. The result shows that it is a uniform dispersion of NCs without any indication of phase separation. However, this method is not desirable because dimethylcadmium is used, which is a pyrophoric and explosive reagent. CdSe NCs obtained from the phosphine-free solvent systems are generally imperfect. The size of CdSe NCs is not easily controlled $[9,32,35]$, and their surface is not suitable for epitaxial 
growth [36, 37]. An environmentally friendly, effective, and ligand exchange-free method should be developed to achieve chemically grafted CPs on the QD surface.

In this paper, two kinds of $\mathrm{P} 3 \mathrm{HT}-\mathrm{COOH} / \mathrm{CdSe}$ nanocomposites were prepared by an in situ synthesis method without using organophosphine as a ligand. The p-type/ntype hybrid nanocomposites have high quality and show fluorescence quenching, indicating an effective charge transfer at the interface between P3HT-COOH and CdSe.

\section{Experiment}

2.1. General Procedures and Chemicals. All reactions were carried out under nitrogen gas flow using a standard Schlenk line. The glassware was predried before use at $120^{\circ} \mathrm{C}$. All chemicals, including 1-octadecene (ODE), trichlorobenzene, selenium powder, ethynylmagnesium bromide $(1 \mathrm{~mol} / \mathrm{L}$ in THF), and P3HT (number average molecular weight was $30,000 \mathrm{~g} / \mathrm{mol}$ ), were purchased from J\&K (China). Cadmium stearate was purchased from Aladdin (China). THF (Aladdin, 99\%) was refluxed over sodium wire.

2.2. Synthesis of Ethynyl-Terminated P3HT. Ethynyl-terminated P3HT (i.e., P3HT-三) was synthesized by the quasiliving Grignard metathesis (GRIM) method [38]. P3HT $(0.09 \mathrm{~g}, 0.03 \mathrm{mmol})$ was dissolved in $20 \mathrm{~mL}$ THF, and $\mathrm{Ni}(\mathrm{dppp}) \mathrm{Cl}_{2}(0.0225 \mathrm{~g}, 0.041 \mathrm{mmol})$ was added. The resulting mixture was first stirred for $10 \mathrm{~min}$ at room temperature, followed by a reaction with ethynylmagnesium bromide $(0.03 \mathrm{~mL}, 0.03 \mathrm{mmol})$ in THF for $30 \mathrm{~min}$. The product, $\mathrm{P} 3 \mathrm{HT}-\equiv$, was obtained by precipitating the reaction mixture in methanol, filtering in an extraction thimble, and washing by Soxhlet extraction with methanol, hexanes, and chloroform sequentially.

2.3. Synthesis of P3HT-COOHs. P3HT-COOHs contain $\mathrm{P} 3 \mathrm{HT}-\mathrm{Z}-\mathrm{COOH}$, and $\mathrm{P} 3 \mathrm{HT}-\mathrm{M}-\mathrm{COOH}$ is synthesized by click reaction [38] (Scheme 1). The 4-aminophenylacetic acid (i.e., Z) and sodium azide were mixed in water to substitute the amino group of 4-aminophenylacetic acid into azide $\left(\mathrm{N}_{3}\right)$, yielding $\mathrm{N}_{3}$-functionalized-phenylacetic acid complexes ( $\mathrm{Z}$ $\mathrm{N}_{3}$ ). The 4-(bromomethyl)benzoic acid (i.e., $\mathrm{M}$ ) and sodium azide were mixed in DMF to substitute the bromide group of 4-(bromomethyl)benzoic acid into azide $\left(\mathrm{N}_{3}\right)$, yielding $\mathrm{N}_{3}$-functionalized-methylbenzoic acid complexes $\left(\mathrm{M}-\mathrm{N}_{3}\right)$.

Subsequently, the synthesized P3HT- $\equiv$ and $\mathrm{Z}-\mathrm{N}_{3}$ or M$\mathrm{N}_{3}$ were mixed in THF and kept at $60^{\circ} \mathrm{C}$ under Ar for 3 days, yielding $\mathrm{P} 3 \mathrm{HT}-\mathrm{Z}-\mathrm{COOH}$ or $\mathrm{P} 3 \mathrm{HT}-\mathrm{M}-\mathrm{COOH}$ complexes. The resulting solution was precipitated in methanol to remove the excess amount of $\mathrm{Z}-\mathrm{N}_{3}$ or $\mathrm{M}-\mathrm{N}_{3}$, which was not coupled with P3HT-三.

2.4. Synthesis of the Se Precursor. Selenium powder $0.079 \mathrm{~g}$ $(1.0 \mathrm{mmol})$ was added to a three-necked flask with $2 \mathrm{~mL}$ of oleylamine and $10 \mathrm{~mL}$ of ODE, and the mixture was then stirred under $\mathrm{Ar}$ at $220^{\circ} \mathrm{C}$ to produce an optically clear solution.

2.5. Synthesis of P3HT-COOH/CdSe Nanocomposites. P3HTCOOHs $0.009 \mathrm{~g}(0.500 \mathrm{mmol})$ and cadmium stearate $0.395 \mathrm{~g}$ $(0.500 \mathrm{mmol})$ were mixed in ODE $(13 \mathrm{~mL})$ and trichloroben- zene $(1 \mathrm{~mL})$ and kept at $220^{\circ} \mathrm{C}$ under Ar until the liquid color was bright orange. The product is P3HT-COO-Cd solution (P3HT-Z-COO-Cd or P3HT-M-COOH-Cd). Subsequently, $10 \mathrm{~mL}$ Se precursor solution was rapidly injected into the $\mathrm{P} 3 \mathrm{HT}-\mathrm{COOH}-\mathrm{Cd}$ solution. The reaction solution color immediately changed to brown from bright orange indicating the formation of CdSe nanoparticles. Nanoparticles were allowed to grow at $220^{\circ} \mathrm{C}$ for $1 \mathrm{~h}$. The resulting P3HT$\mathrm{COOH} / \mathrm{CdSe}$ nanocomposites were cooled down and precipitated with methanol and redissolved in chloroform.

\section{Characterizations}

The morphology of P3HT-COOH/CdSe nanocomposites was imaged by using transmission electron microscopes (Tecnai G2 F20 S-TWIN, FEI). The absorption and emission spectra were recorded with a UV-vis spectrometer (UV2600, Shimadzu) and a spectrofluorophotometer (CaryEclipse, Varian), respectively. All samples were excited at $\lambda_{\mathrm{ex}}=445 \mathrm{~nm}$, and the emission was collected at $\lambda_{\mathrm{em}}>400$ $\mathrm{nm}$. The Fourier transform infrared spectroscopy (FT-IR) spectra were obtained using a FT-IR spectrometer (FTIR8400s, Shimadzu). The X-ray diffraction (XRD) (XD8-AdranceX, Bruker Corporation, Germany) measurement was carried out using a Cu-K $\alpha$ radiation source $(\lambda=1.5418 \AA$ ), and the $2 \theta$ range used was from $5^{\circ}$ to $80^{\circ}$.

\section{Results and Discussion}

The synthesis routes of $\mathrm{P} 3 \mathrm{HT}-\mathrm{COOH} / \mathrm{CdSe}$ nanocomposites are illustrated in Scheme 2. The P3HT-COOH (e.g., P3HT$\mathrm{M}-\mathrm{COOH}$ and $\mathrm{P} 3 \mathrm{HT}-\mathrm{Z}-\mathrm{COOH}$ in Scheme 1) plays an important role in the synthesis of CdSe nanocrystals. The growth process of nanocrystals can be controlled via P3HT$\mathrm{COOH}$ as a template. First of all, according to a recent report, the carboxyl of $\mathrm{P} 3 \mathrm{HT}-\mathrm{COOH}$ can react with $\mathrm{Cd}^{2+}$ to form P3HT-COO-Cd compounds linked by metal carboxylate linkage $[39,40]$. The Se precursor was then injected and subjected to a subsequent nucleation-and-growth process.

FT-IR spectroscopy in Figures 1(a) and 1(b) was used to identify and characterize the metal carboxylate linkage between $\mathrm{Cd}^{2+}$ and -COOH. In Figure 1(a), the absorption peaks at $1639 \mathrm{~cm}^{-1}$ and $3433 \mathrm{~cm}^{-1}$ assigned to the characteristic $\mathrm{C}=\mathrm{O}$ stretching vibration and $-\mathrm{O}-\mathrm{H}$ stretching vibration of P3HT-Z-COOH disappeared in the FT-IR spectrum of $\mathrm{P} 3 \mathrm{HT}-\mathrm{Z}-\mathrm{COOH} / \mathrm{CdSe}$ nanocomposites, and the absorption peaks at $1556 \mathrm{~cm}^{-1}$ (carboxylate stretching) appeared, clearly indicating the success of chemical coupling (see Scheme 1) between $\mathrm{CdSe}$ and P3HT-Z-COOH. The same happens in Figure 1(b). Figure 1(c) compares the FT-IR spectra of $\mathrm{P} 3 \mathrm{HT}-\mathrm{Z}-\mathrm{COOH} / \mathrm{CdSe}$ nanocomposites and P3HT-M$\mathrm{COOH} / \mathrm{CdSe}$ nanocomposites. As shown in the FT-IR spectra, the $-\mathrm{CH}_{2}$ - characteristic vibration shifts from 1103 to $991 \mathrm{~cm}^{-1}$ due to the different locations of $-\mathrm{CH}_{2}$ - in the two kinds of P3HT-COOHs.

The high boiling point solvent ODE was employed to dissolve P3HT-COO-Cd (P3HT-Z-COO-Cd and P3HT$\mathrm{M}-\mathrm{COO}-\mathrm{Cd}$ ) for the synthesis of high-quality $\mathrm{P} 3 \mathrm{HT}$ $\mathrm{COOH} / \mathrm{CdSe} \mathrm{NC}$ nanocomposites. The injection of Se- 


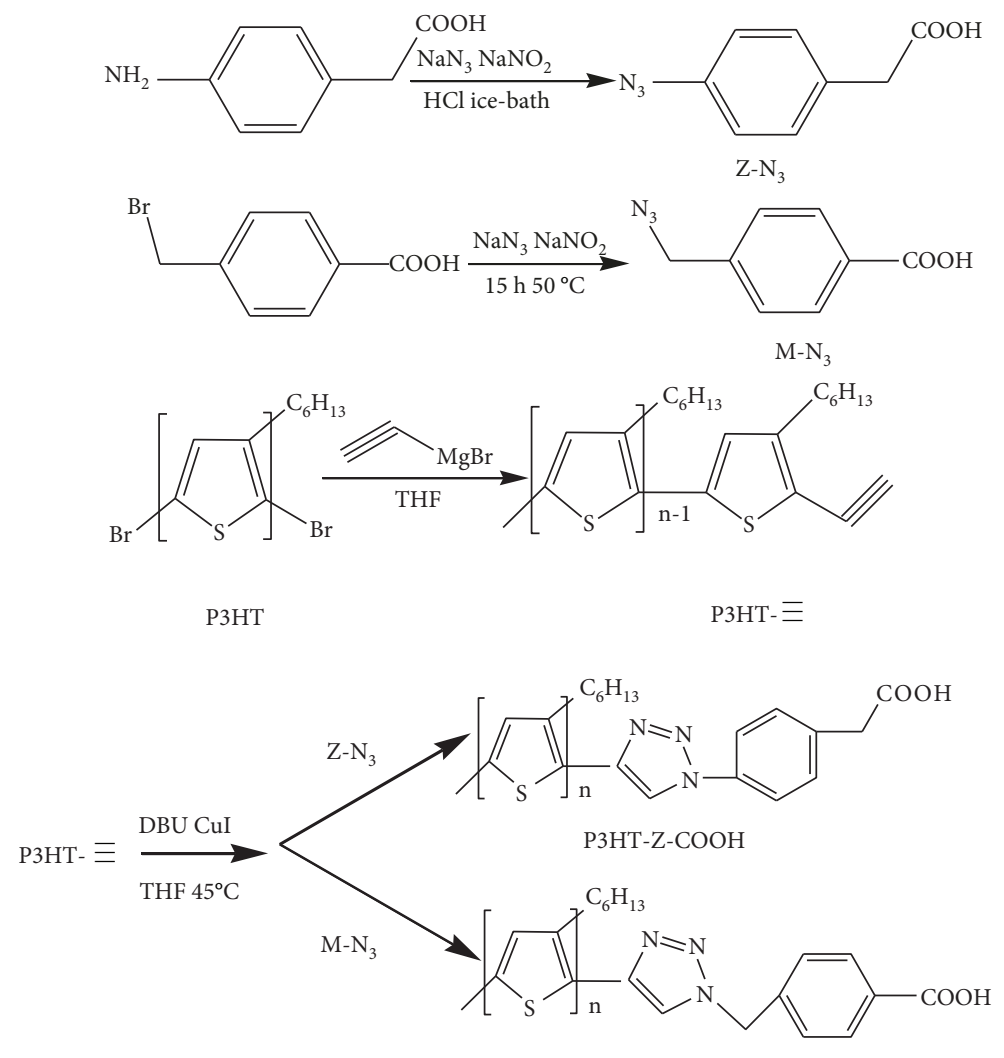

P3HT-M-COOH

Scheme 1: Synthetic route to P3HT-COOHs by click reaction.

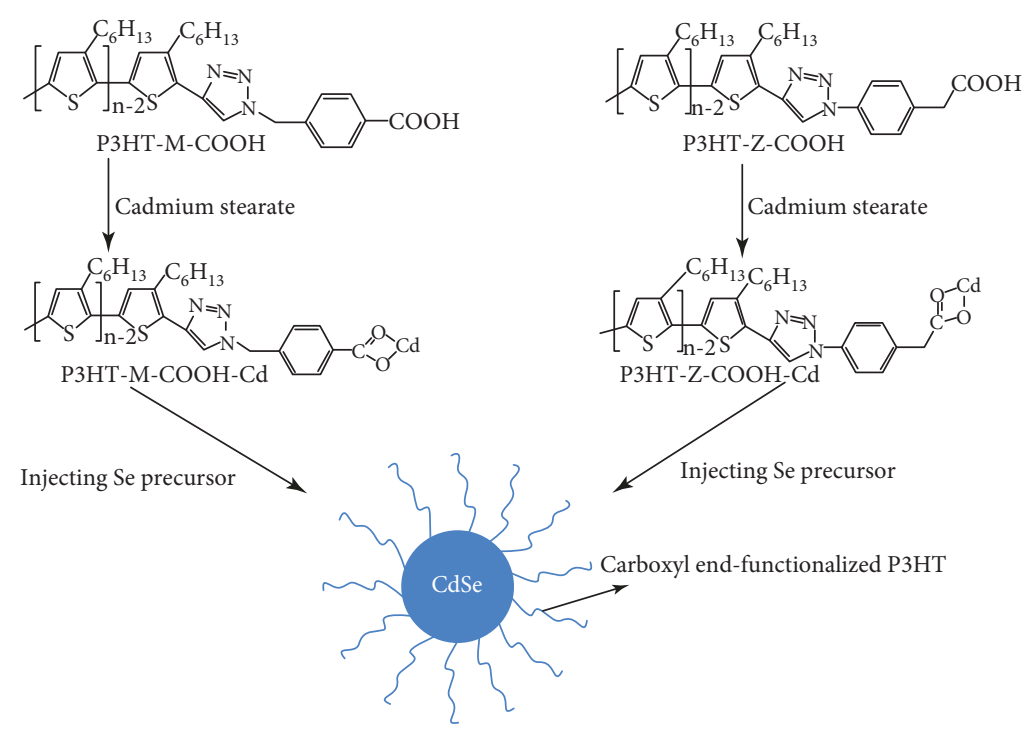

Scheme 2: Synthetic route to carboxyl end-functionalized P3HT/CdSe nanocomposites by P3HT-M-COOH (left panel) and P3HT-Z-COOH (right panel).

oleylamine solution initiated the nucleation and growth of CdSe NCs having direct contact with P3HT-COOH (see Experiment). The presence of $\mathrm{P} 3 \mathrm{HT}-\mathrm{COOH}$ imposed steric hindrance during the growth of CdSe NCs, thereby preventing the agglomeration of CdSe NCs.
As a result, despite the absence of hazardous organometallic ligands (e.g., widely used tri-n-octylphosphine oxide (TOPO) and trioctylphosphine (TOP) for high-quality CdSe QD synthesis), uniform CdSe QDs tethered with P3HT chains were obtained. It is clear that transmission electron 


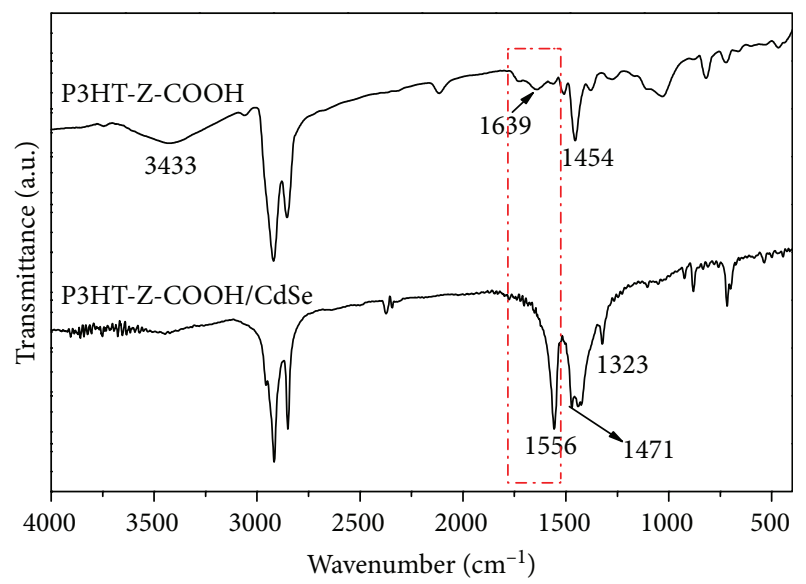

(a)

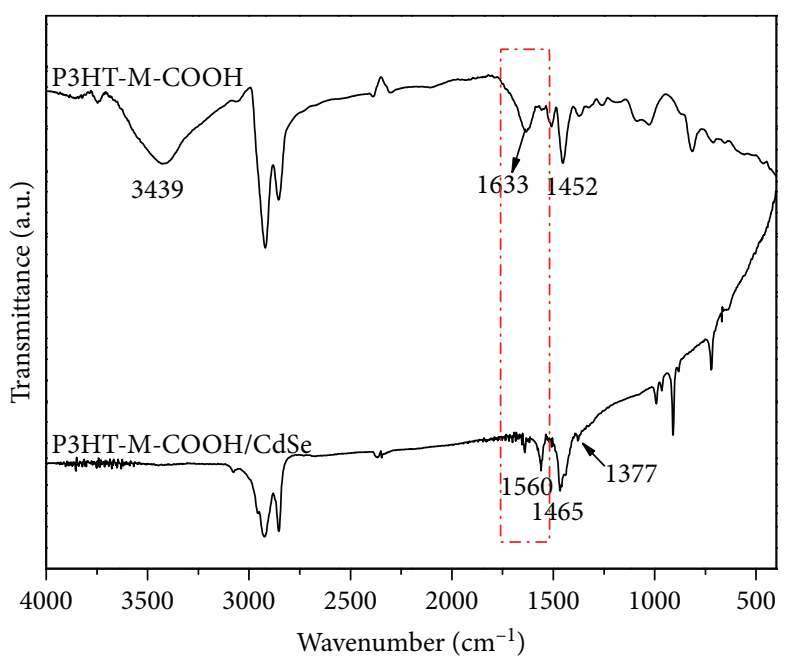

(b)

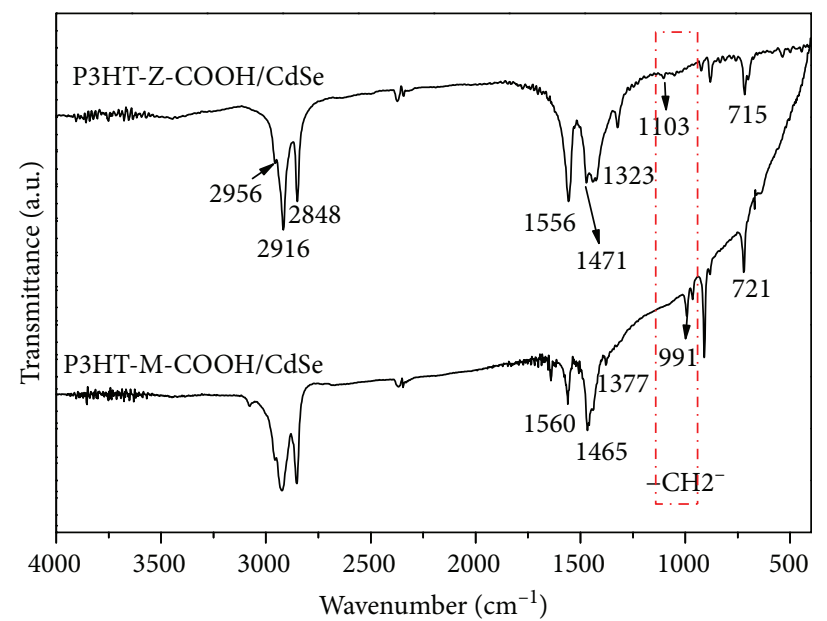

(c)

Figure 1: (a) FTIR spectrum of P3HT-Z-COOH and P3HT-Z-COOH/CdSe. (b) FTIR spectrum of P3HT-M-COOH and P3HT-M$\mathrm{COOH} / \mathrm{CdSe}$. (c) FTIR spectra of P3HT-Z-COOH/CdSe nanocomposites and P3HT-M-COOH/CdSe nanocomposites.

microscopy (TEM) measurements revealed a homogeneous dispersion of $\mathrm{P} 3 \mathrm{HT}-\mathrm{COOH} / \mathrm{CdSe}$ QD nanocomposites as shown in Figure 2. The diameters of these spherical CdSe nanocrystals increase to about $6.7 \mathrm{~nm}$ (P3HT-Z$\mathrm{COOH} / \mathrm{CdSe}$ ) and $7.9 \mathrm{~nm}(\mathrm{P} 3 \mathrm{HT}-\mathrm{M}-\mathrm{COOH} / \mathrm{CdSe})$, respectively. It must be pointed out that the diameters of these spherical CdSe nanocrystals can be controlled by changing reaction conditions. In the same reaction time, the size of P3HT-M-COOH/CdSe NCs increased more obviously than $\mathrm{P} 3 \mathrm{HT}-\mathrm{Z}-\mathrm{COOH} / \mathrm{CdSe} \mathrm{NCs}$, revealing that $\mathrm{P} 3 \mathrm{HT}-\mathrm{M}-\mathrm{COOH}$ is more effective for nucleation and growth of nanocrystals as the polymer matrix. It was found in TEM images that there is a narrow size distribution of the nanoparticles, and the shapes of these nanocrystals are regular, the dispersion of CdSe nanoparticles in P3HT-COOH is greatly improved, and the majority of the nanoparticles are spherical with an average grain size of 6 to $8 \mathrm{~nm}$.

The photophysical properties of the resulting P3HT$\mathrm{COOH} / \mathrm{CdSe}$ nanocomposites were examined by UV-vis absorbance and photoluminescence (PL) studies. The absorp- tion spectra of $\mathrm{P} 3 \mathrm{HT}-\mathrm{COOH} / \mathrm{CdSe}$ nanocomposites are shown in Figure 3. As seen from Figure 3(a), the peak at $636 \mathrm{~nm}$ and $652 \mathrm{~nm}$ corresponds to P3HT-Z-COOH/CdSe and P3HT-M-COOH/CdSe absorption, respectively. The diameters of these spherical CdSe nanocrystals obtained by the calculation according to published equations [41] are consistent with the observation from TEM images. After the carboxyl functionalization, their optical properties both varied and the wavelength range of nanocomposites exhibited a red shift in comparison with the $\mathrm{P} 3 \mathrm{HT} / \mathrm{CdSe}$ nanocomposite [42]; it means that the size of the nanocomposites increased, indicating that carboxyl functionalization is sufficient for forming size-tunable P3HT-COOH/CdSe nanocomposites. In comparison with $\mathrm{P} 3 \mathrm{HT} / \mathrm{CdSe}$ nanocomposites [42], the size of P3HT-M-COOH/CdSe nanocomposites increased more obviously than that of P3HT-Z-COOH/CdSe NCs, which is in line with the TEM analysis.

The PL spectra of P3HT-Z-COOH/CdSe nanocomposites and P3HT-M-COOH/CdSe nanocomposites are shown in Figure 3(b). In contrast with P3HT-COOHs, nearly complete 


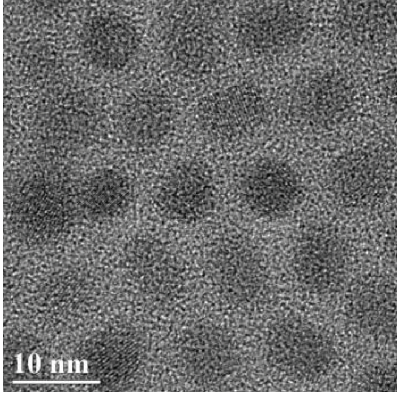

(a)

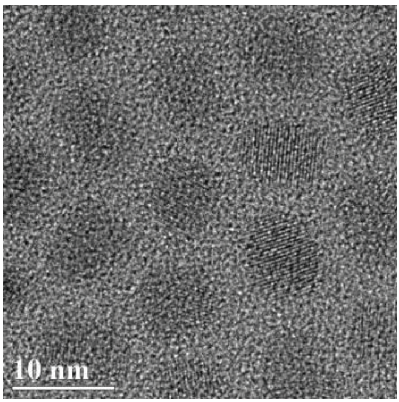

(c)

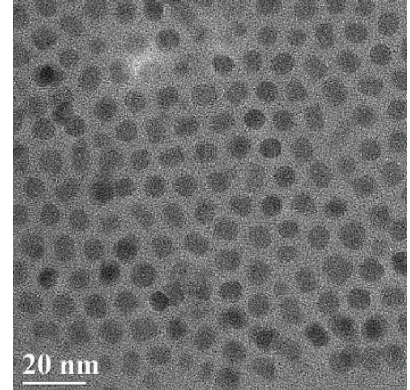

(b)

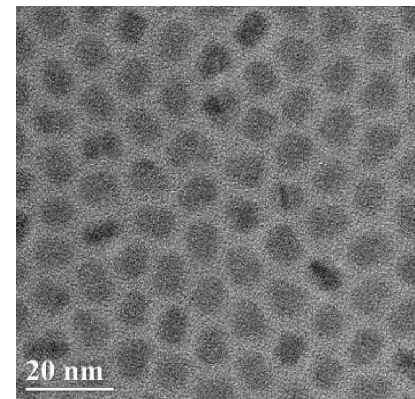

(d)

FIgURE 2: TEM images of P3HT-Z-COOH/CdSe nanocomposites ( $a, b)$ and P3HT-M-COOH/CdSe nanocomposites (c, d).
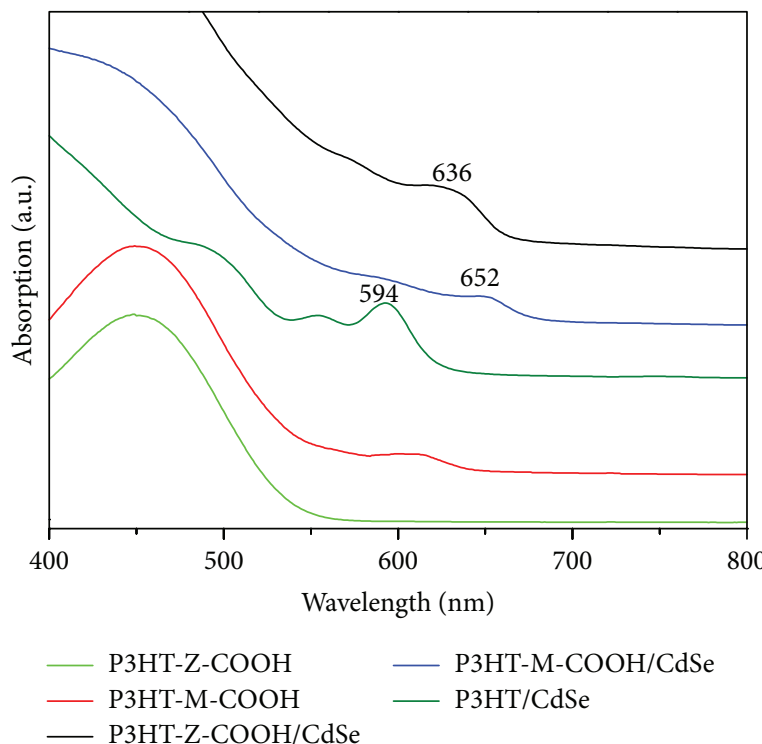

(a)

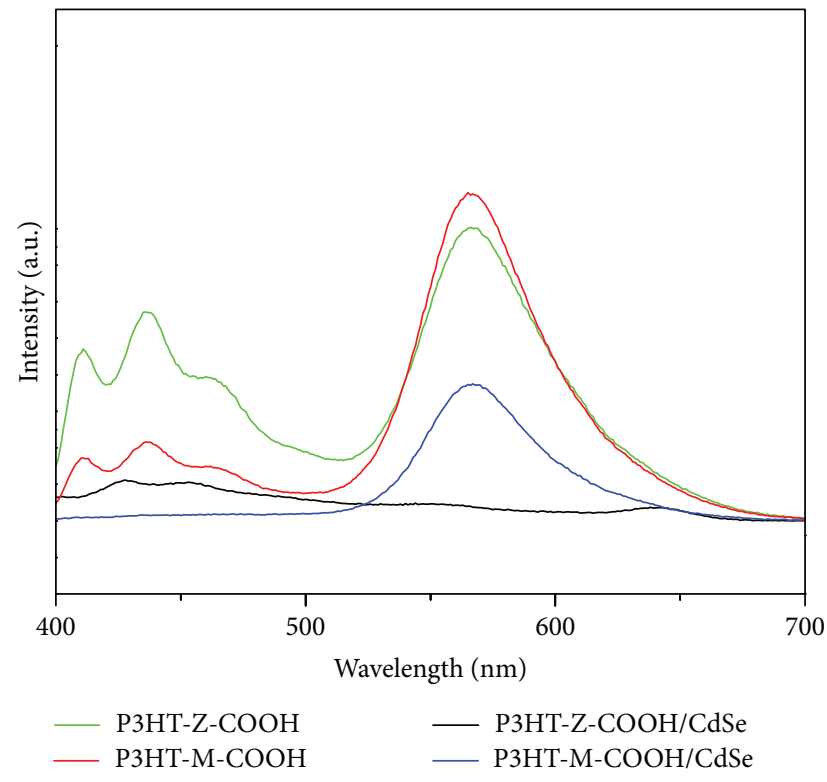

(b)

FIGURE 3: UV-vis spectra (a) and photoluminescence spectra (b) of P3HT-COOH/CdSe nanocomposites.

quenching of nanocomposite fluorescence was seen, implying efficient charge transfer from P3HT-COOHs to CdSe NCs. This observation further confirmed intimate chemical contact between P3HT-COOHs and CdSe NCs. It must be mentioned that the PL intensity of P3HT-M-COOH/CdSe nanocomposites is relatively higher. In contrast, nearly complete quenching of $\mathrm{P} 3 \mathrm{HT}-\mathrm{Z}-\mathrm{COOH} / \mathrm{CdSe}$ nanocomposite fluorescence was seen. One of the possible reasons for the different PL intensities could be attributed to different chemical structures of the two P3HT-COOHs. In P3HT-M-COOH, the carboxyl group is connected with phenyl. On the contrary, the carboxyl group is connected with methylene in P3HT-Z-COOH. Methylene has lower steric hindrance so that it can react with the CdSe NCs more easily. In 


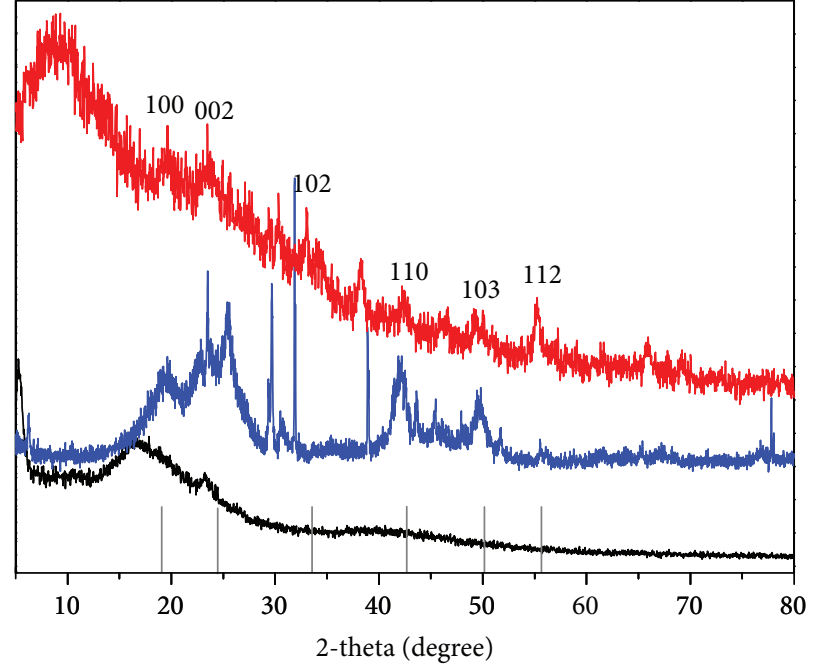

- CdSe-P3HT-Z-COOH
- CdSe
P3HT-Z-COOH

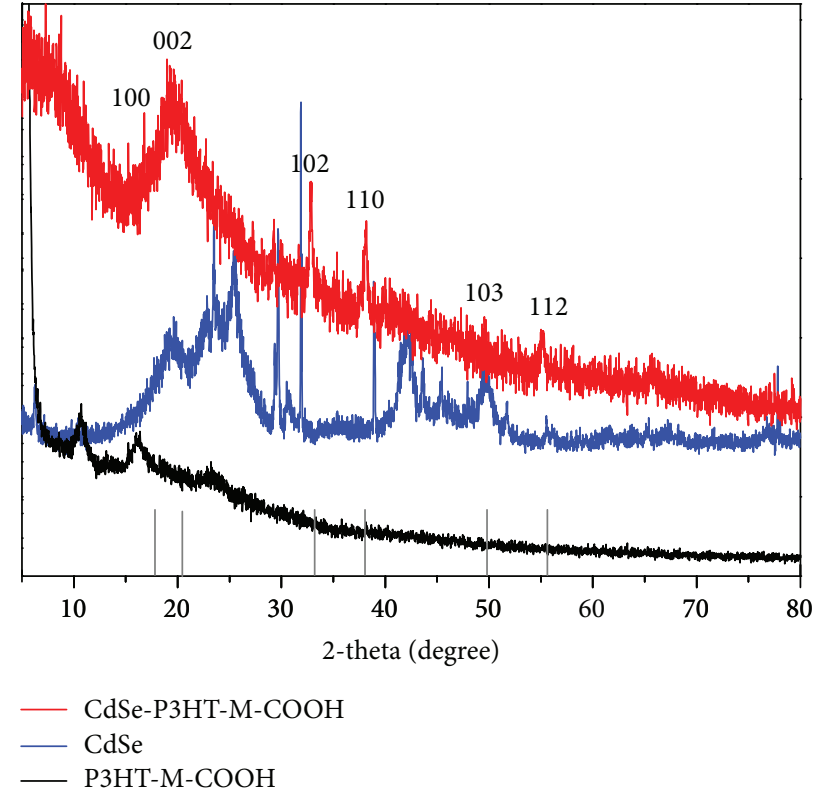

(b)

Figure 4: XRD patterns of P3HT-COOH/CdSe nanocomposites: (a) P3HT-Z-COOH/CdSe; (b) P3HT-M-COOH/CdSe.

comparison to the P3HT/CdSe nanocomposites [42], the significant PL quenching of nanocomposites after the carboxyl functionalization suggested the efficient charge transfer from P3HT-COOHs to CdSe NCs, which confirmed the intimate chemical contact between P3HT-COOH and CdSe QDs.

$\mathrm{X}$-ray diffraction (XRD) analysis was performed to investigate the crystalline structure of $\mathrm{P} 3 \mathrm{HT}-\mathrm{COOH} / \mathrm{CdSe}$ nanocomposites (Figure 4). In the XRD patterns of the carboxyl end-functionalized P3HT/CdSe nanoparticles, a series of characteristic peaks of (100), (002), (102), (110), (103), and (112) are observed, which are in accordance with the wurtzite phase of CdSe Qdots (JCPD No. 08-0456). Moreover, in TEM images, the lattice spacing of the spherical CdSe nanocrystals is $0.35 \mathrm{~nm}$, corresponding to the (111) plane of cubic CdSe.

\section{Conclusions}

In summary, we demonstrated phosphine-free synthetic routes of P3HT-COOH/CdSe nanocomposites to achieve chemical tethering between the polymer matrix and the NC surface. P3HT-COOH can first react with $\mathrm{Cd}^{2+}$ to form P3HT-COOCd compounds linked by a metal carboxylate linkage. The precursor of Se was then injected and subjected to a subsequent nucleation-and-growth process. The scrutiny on the effects of $\mathrm{P} 3 \mathrm{HT}-\mathrm{COOH} / \mathrm{CdSe}$ nanocomposites revealed that the carboxyl end-functionalized $\mathrm{P} 3 \mathrm{HT}$ s were more effective in improving the characteristics of CdSe NCs than the pure P3HT and promoted CdSe NCs' effective charge transport and good dispersion of nanoparticles. In addition, the particle size of CdSe NCs was controllable. Therefore, this phosphine-free method provides a promising platform to craft a variety of functionalized polymernanocrystal nanocomposites.

\section{Data Availability}

The experimental data used to support the findings of this study are included within the article.

\section{Conflicts of Interest}

There are no conflicts to declare.

\section{Acknowledgments}

This work was supported by the Natural Science Foundation of Inner Mongolia (grant no. 2017MS0202).

\section{References}

[1] W. U. Huynh, J. J. Dittmer, and A. P. Alivisatos, "Hybrid Nanorod-Polymer Solar Cells," Science, vol. 295, no. 5564, pp. 2425-2427, 2002.

[2] S. H. Choi, H. Song, I. K. Park et al., "Synthesis of sizecontrolled CdSe quantum dots and characterization of CdSeconjugated polymer blends for hybrid solar cells," Journal of Photochemistry and Photobiology A: Chemistry, vol. 179, no. 1-2, pp. 135-141, 2006.

[3] J. D. Olson, G. P. Gray, and S. A. Carter, "Optimizing hybrid photovoltaics through annealing and ligand choice," Solar Energy Materials and Solar Cells, vol. 93, no. 4, pp. 519-523, 2009.

[4] S. Dayal, N. Kopidakis, D. C. Olson, D. S. Ginley, and G. Rumbles, "Direct Synthesis of CdSe Nanoparticles in Poly(3-hexylthiophene)," Journal of the American Chemical Society, vol. 131, no. 49, pp. 17726-17727, 2009.

[5] R. Liu, "Hybrid Organic/Inorganic Nanocomposites for Photovoltaic Cells," Materials, vol. 7, no. 4, pp. 2747-2771, 2014. 
[6] A. Smeets, K. Van den Bergh, J. De Winter, P. Gerbaux, T. Verbiest, and G. Koeckelberghs, "Incorporation of Different End Groups in Conjugated Polymers Using Functional Nickel Initiators," Macromolecules, vol. 42, no. 20, pp. 7638-7641, 2009.

[7] S. Ren, L. Y. Chang, S. K. Lim et al., "Inorganic-Organic Hybrid Solar Cell: Bridging Quantum Dots to Conjugated Polymer Nanowires," Nano Letters, vol. 11, no. 9, pp. 39984002, 2011.

[8] A. Smeets, P. Willot, J. De Winter, P. Gerbaux, T. Verbiest, and G. Koeckelberghs, "End Group-Functionalization and Synthesis of Block-Copolythiophenes by Modified Nickel Initiators," Macromolecules, vol. 44, no. 15, pp. 6017-6025, 2011.

[9] F. Alam, N. Kumar, and V. Dutta, "Study of surfactant-free lead sulfide nanocrystals-P3HT hybrid polymer solar cells," Organic Electronics, vol. 22, pp. 44-50, 2015.

[10] L. Li, M. J. Greaney, K. Li, A. Sachdeva, R. L. Brutchey, and J. C. Campbell, "Effects of surface ligands on energetic disorder and charge transport of P3HT:CdSe hybrid solar cells," Physica Status Solidi B, vol. 252, no. 6, pp. 1325-1333, 2015.

[11] D. Loubiri, Z. Ben Hamed, S. Ilahi, M. A. Sanhoury, F. Kouki, and N. Yacoubi, "Effect of TBPO-capped CdSe nanoparticles concentration on sub-bandgap absorption in poly(3-hexylthiophene) thin films studied by photothermal deflection spectroscopy," Synthetic Metals, vol. 206, pp. 1-7, 2015.

[12] J. Jung, Y. J. Yoon, M. He, and Z. Lin, "Organic-inorganic nanocomposites composed of conjugated polymers and semiconductor nanocrystals for photovoltaics," Journal of Polymer Science Part B: Polymer Physics, vol. 52, no. 24, pp. 1641-1660, 2014.

[13] G. Grancini, M. Biasiucci, R. Mastria et al., "Dynamic Microscopy Study of Ultrafast Charge Transfer in a Hybrid P3HT/Hyperbranched CdSe Nanoparticle Blend for Photovoltaics," The Journal of Physical Chemistry Letters, vol. 3, no. 4, pp. 517-523, 2012.

[14] L. Zhao and Z. Lin, "Crafting Semiconductor OrganicInorganic Nanocomposites via Placing Conjugated Polymers in Intimate Contact with Nanocrystals for Hybrid Solar Cells," Advanced Materials, vol. 24, no. 32, pp. 4353-4368, 2012.

[15] W. M. Kochemba, D. L. Pickel, B. G. Sumpter, J. Chen, and S. M. Kilbey II, "In Situ Formation of Pyridyl-Functionalized Poly(3-hexylthiophene)s via Quenching of the Grignard Metathesis Polymerization: Toward Ligands for Semiconductor Quantum Dots," Chemistry of Materials, vol. 24, no. 22, pp. 4459-4467, 2012.

[16] H. Ma, H. Gao, Z. Zhou, W. Xu, and F. Ren, "Direct Synthesis of P3HT/CdS Nanocomposites With End-functionalized P3HT as the Template," Polymers \& Polymer Composites, vol. 23, no. 7, pp. 435-442, 2015.

[17] N. V. Handa, A. V. Serrano, M. J. Robb, and C. J. Hawker, "Corrigendum: Exploring the synthesis and impact of endfunctional poly(3-hexylthiophene)," Journal of Polymer Science Part A: Polymer Chemistry, vol. 53, no. 15, pp. 1841-1841, 2015.

[18] J. Liu, T. Tanaka, K. Sivula, A. P. Alivisatos, and J. M. J. Fréchet, "Employing End-Functional Polythiophene To Control the Morphology of Nanocrystal-Polymer Composites in Hybrid Solar Cells," Journal of the American Chemical Society, vol. 126, no. 21, pp. 6550-6551, 2004.

[19] M. Wright and A. Uddin, "Organic-inorganic hybrid solar cells: A comparative review," Solar Energy Materials and Solar Cells, vol. 107, pp. 87-111, 2012.
[20] R. A. Krüger, T. J. Gordon, T. Baumgartner, and T. C. Sutherland, "End-Group Functionalization of Poly(3-hexylthiophene) as an Efficient Route to Photosensitize Nanocrystalline TiO2 Films for Photovoltaic Applications," ACS Applied Materials \& Interfaces, vol. 3, no. 6, pp. 20312041, 2011.

[21] F. Boon, A. Thomas, G. Clavel et al., "Synthesis and characterization of carboxystyryl end-functionalized poly(3-hexylthiophene)/TiO2 hybrids in view of photovoltaic applications," Synthetic Metals, vol. 162, no. 17-18, pp. 1615-1622, 2012.

[22] H. Nakashima, K. Furukawa, K. Ajito, Y. Kashimura, and K. Torimitsu, "Selective Chemisorption of End-Functionalized Conjugated Polymer on Macro- and Nanoscale Surfaces," Langmuir, vol. 21, no. 2, pp. 511-515, 2005.

[23] H.-C. Liao, S.-Y. Chen, and D.-M. Liu, "In-Situ Growing CdS Single-Crystal Nanorods via P3HT Polymer as a Soft Template for Enhancing Photovoltaic Performance," Macromolecules, vol. 42, no. 17, pp. 6558-6563, 2009.

[24] V. Kazukauskas, E. Couderc, A. Sakavicius et al., "Analysis of carrier transport in photovoltaic structures of $\mathrm{P} 3 \mathrm{HT}$ with CdSe nanocrystals," Applied Surface Science, vol. 334, pp. 169-173, 2015.

[25] S. Dayal, H. Z. Zhong, N. Kopidakis, G. D. Scholes, and G. Rumbles, "Improved power conversion efficiency for bulk heterojunction solar cells incorporating CdTe-CdSe nanoheterostructure acceptors and a conjugated polymer donor," Journal of Photonics for Energy, vol. 5, no. 1, p. 057409, 2015.

[26] F. A. Roghabadi, M. Kokabi, V. Ahmadi, and G. Abaeiani, "Structure optimization of P3HT:CdSe hybrid solar cell using optical analysis and electrochemical impedance spectroscopy," Thin Solid Films, vol. 621, pp. 19-25, 2017.

[27] J. Lee, J. Lee, J. Yang, T. Park, S. J. Ahn, and W. Yi, “Polymer Quantum Dot-Sensitized Solar Cell Incorporating SingleWalled Carbon Nanotubes," Journal of Nanoscience and Nanotechnology, vol. 17, no. 8, pp. 5496-5500, 2017.

[28] J. Jung, Y. J. Yoon, and Z. Lin, "Intimate organic-inorganic nanocomposites via rationally designed conjugated polymergrafted precursors," Nanoscale, vol. 8, no. 36, pp. 16520 16527, 2016.

[29] S. M. Jin, I. Kim, J. A. Lim, H. Ahn, and E. Lee, "Interfacial Crystallization-Driven Assembly of Conjugated Polymers/Quantum Dots into Coaxial Hybrid Nanowires: Elucidation of Conjugated Polymer Arrangements by Electron Tomography," Advanced Functional Materials, vol. 26, no. 19, pp. 3226-3235, 2016.

[30] S. Bera and S. K. Ray, "The Role of Nanocrystal Size in Solution Processable CdSe:P3HT Hybrid Photovoltaic Devices," Journal of Nanoscience and Nanotechnology, vol. 16, no. 5, pp. 4840-4845, 2016.

[31] A. Benchaabane, Z. Ben Hamed, A. Lahmar et al., "Optical properties of P3HT:tributylphosphine oxide-capped CdSe nanocomposites," Applied Physics A, vol. 122, no. 8, pp. 720 724, 2016.

[32] S. Sapra, A. L. Rogach, and J. Feldmann, "Phosphine-free synthesis of monodisperse CdSe nanocrystals in olive oil," Journal of Materials Chemistry, vol. 16, no. 33, pp. 3391-3395, 2006.

[33] J. Jasieniak, C. Bullen, J. van Embden, and P. Mulvaney, "Phosphine-Free Synthesis of CdSe Nanocrystals," The Journal of Physical Chemistry B, vol. 109, no. 44, pp. 20665-20668, 2005.

[34] S. Asokan, K. M. Krueger, A. Alkhawaldeh et al., "The use of heat transfer fluids in the synthesis of high-quality CdSe 
quantum dots, core/shell quantum dots, and quantum rods," Nanotechnology, vol. 16, no. 10, pp. 2000-2011, 2005.

[35] M. Sun and X. Yang, "Phosphine-Free Synthesis of HighQuality CdSe Nanocrystals in Noncoordination Solvents: "Activating Agent" and "Nucleating Agent" Controlled Nucleation and Growth," Journal of Physical Chemistry C, vol. 113, no. 20, pp. 8701-8709, 2009.

[36] L. J. Zhang, X. C. Shen, and H. Liang, "A Mild Phosphine-Free Synthesis of Alkylamine-Capped CdSe Nanocrystals," Journal of Nanoscience and Nanotechnology, vol. 10, no. 8, pp. 49794984, 2010.

[37] F. Monnaie, W. Brullot, T. Verbiest et al., "Synthesis of EndGroup Functionalized P3HT: General Protocol for P3HT/Nanoparticle Hybrids," Macromolecules, vol. 46, no. 21, pp. 8500-8508, 2013.

[38] M. Urien, H. Erothu, E. Cloutet, R. C. Hiorns, L. Vignau, and H. Cramail, "Poly(3-hexylthiophene) Based Block Copolymers Prepared by "Click" Chemistry," Macromolecules, vol. 41, no. 19, pp. 7033-7040, 2008.

[39] P. E. Chen, N. C. Anderson, Z. M. Norman, and J. S. Owen, "Tight Binding of Carboxylate, Phosphonate, and Carbamate Anions to Stoichiometric CdSe Nanocrystals," Journal of the American Chemical Society, vol. 139, no. 8, pp. 3227-3236, 2017.

[40] N. C. Anderson, M. P. Hendricks, J. J. Choi, and J. S. Owen, "Ligand Exchange and the Stoichiometry of Metal Chalcogenide Nanocrystals: Spectroscopic Observation of Facile Metal-Carboxylate Displacement and Binding," Journal of the American Chemical Society, vol. 135, no. 49, pp. 1853618548, 2013.

[41] W. W. Yu, L. Qu, W. Guo, and X. Peng, "Experimental Determination of the Extinction Coefficient of CdTe, CdSe, and CdS Nanocrystals," Chemistry of Materials, vol. 15, no. 14, pp. 2854-2860, 2003.

[42] F. F. Chang, Preparation and performance of nanocomposites based on CdE nanocrastals and P3HT derivatives. (Master's degree), Inner Mongolia University of technology, Hohhot, China, 2015. 


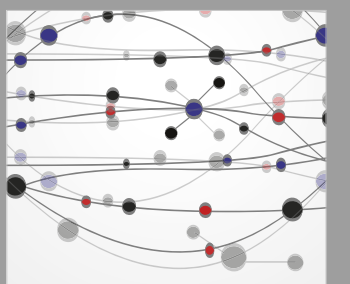

The Scientific World Journal
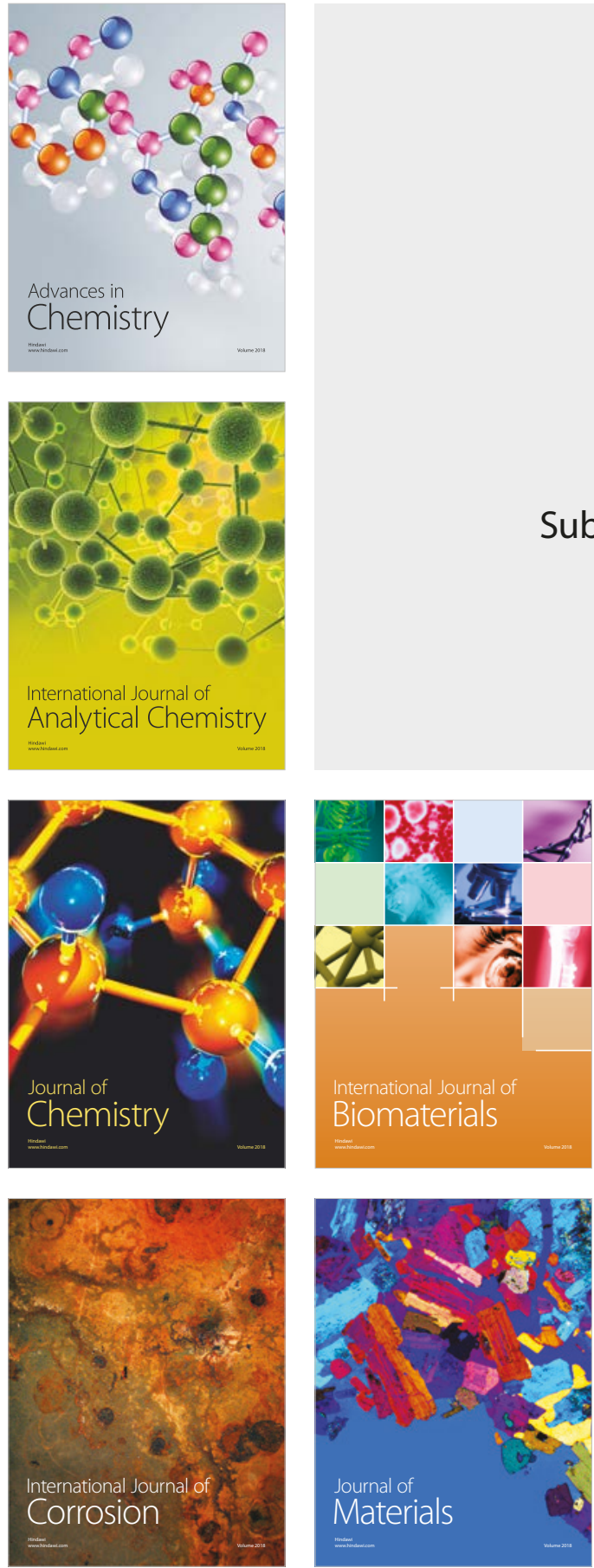

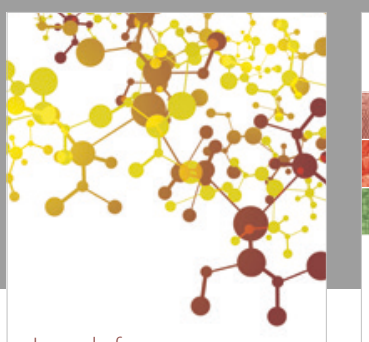

Journal of

Applied Chemistry
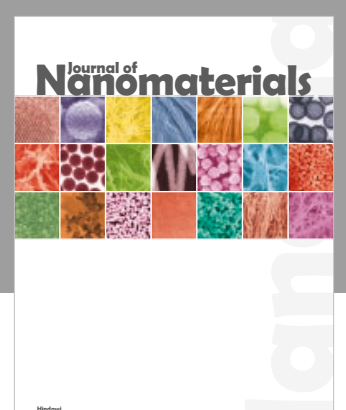

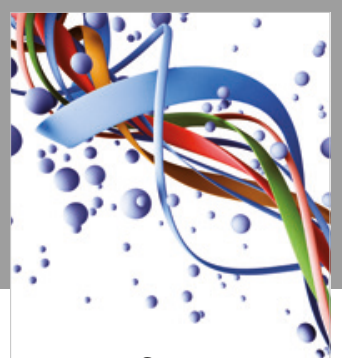

Scientifica

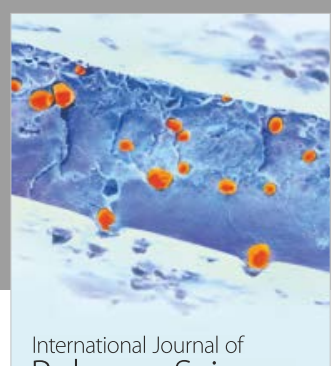

Polymer Science

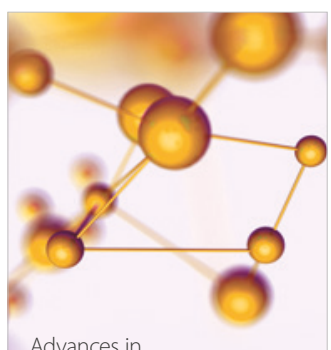

Physical Chemistry
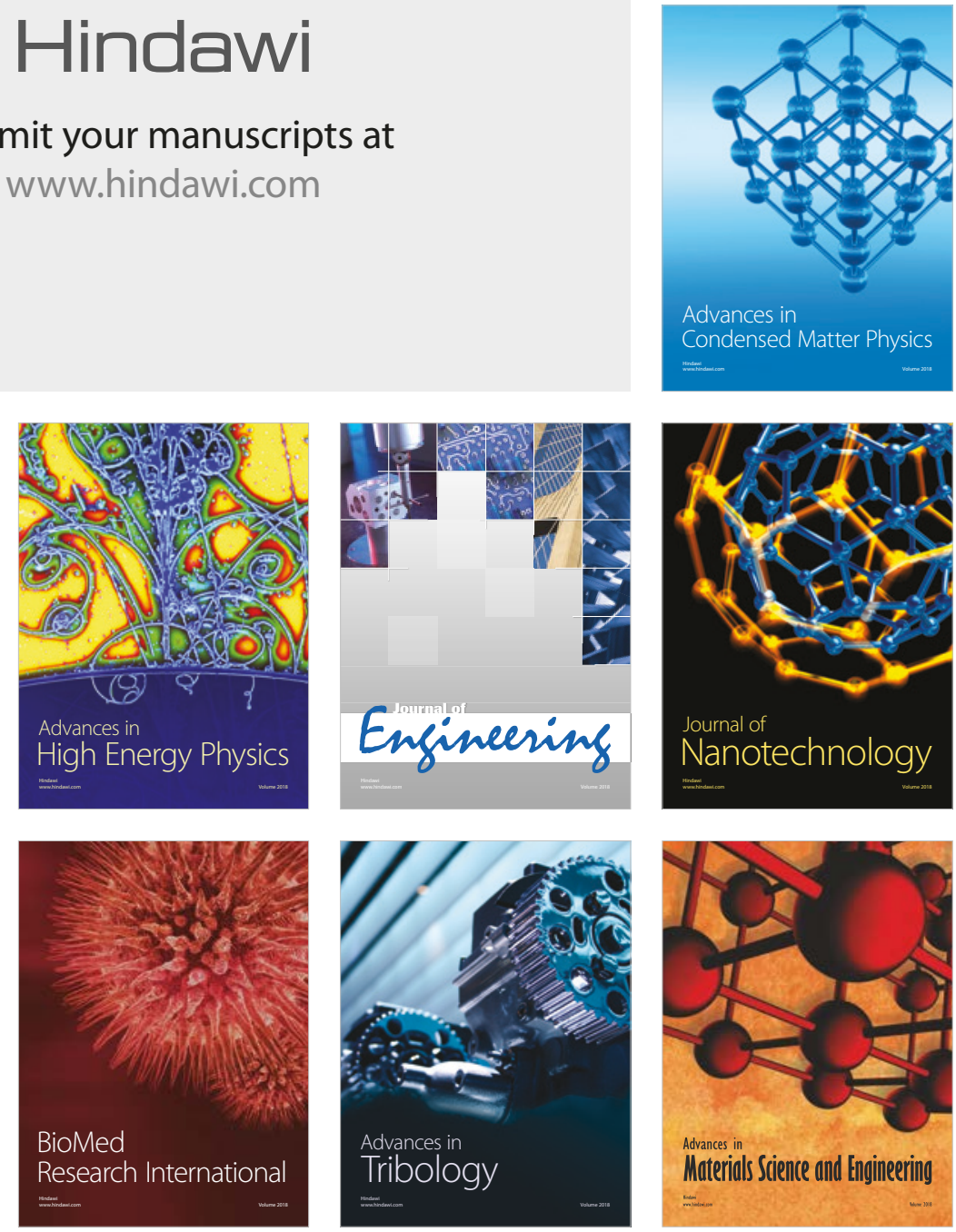